Involvement of such a method is not accidental. The revealed grammatical transposition reduces the functions of the main characters exclusively to the depiction of certain traits or moral qualities. At the mental level, they cease to be perceived by the reader as figures, but only create a background and a favourable environment for the development of a key image-symbol.

\title{
References:
}

1. Znamenskaya, T. A. (2004). Stilistika angliyskogo yazyka. Osnovy kursa [Stylistics of the English language. Course Basics]. Moscow: Editorial. (in Russian)

2. Panther, K-U. \& Thornburg, L. L. (2009). Introduction on figuration in grammar. Metonymy and Metaphor in Grammar (eds. K. Panther, L. L. Thornburg \& A. Barcelona). San Diego: John Benjamins, vol. 25, pp. 3-40.

3. Arutyunova, N. D. (1990). Obraz, metafora, simvol v kontekste zhizni i kul'tury [Image, metaphor, symbol under the life and culture context]. Res Philologica. Filologicheskie issledovaniya [Res Philologica. Philological research]. Moscow: Nauka, pp. 71-88.

4. Hawthorne, N. (1994). The Scarlet Letter. London: PENGUIN BOOKS.

5. Cirlot, J. E. (2001). A Dictionary of Symbols. $2^{\text {nd }}$ edition (translated from the Spanish by Jack Sage). London: Taylor \& Francis e-Library.

6. Ferber, M. (1999). A Dictionary of Literary Symbols. New York: Cambridge University Press.

7. Kukharenko, V. A. (2004). Interpretatsiia tekstu [Text interpretation]. Vinnytsia: Nova Knyha. (in Ukrainian)

8. Stockwell, P. (2005). Cognitive Poetics. An Introduction. London; New York: Taylor \& Francis e-Library.

\section{CORRESPONDENCE BETWEEN W. CHURCHILL AND F. ROOSEVELT: GENRE-STYLE DOMINANTS}

\section{Olga Semeniuk ${ }^{1}$}

\section{DOI: https://doi.org/10.30525/978-9934-588-52-5-12}

Recent studies in epistolography scrutinize the genre nature of writers' epistolary that has attracted the close attention of many scholars. Despite the fact that for the last decades the study of such a phenomenon in literature as the writer's epistolary has been giving a rise to controversy and divergent views of most scholars on the issues related to the specificity, genre nature,

\footnotetext{
${ }^{1}$ Educational \& Scientific Center of Language Training of the National Academy of the Security Service of Ukraine, Ukraine
} 
stylistic colour and aesthetic value of the epistolary of Winston Churchill, an outstanding politician, the priority is given to private correspondence in the system of memoirs because in private letters the writer reveals his true face: an authentic portrait, a photograph of thought and judgment. Due to the fact that Winston Churchill's epistolary heritage contains the trove of private and business correspondences as well which were regarded mainly as commentaries on his nonfiction works and his political activities without taking into consideration both the artistic and historical value, genre-style originality of the writer's epistolary, there is a need for a comprehensive approach to studying the writer's epistolary, a deeper immersion in the nature and structure of the writer's epistolary style, taking into account the changes and new trends emerging in modern literary criticism and epistolography resulting from new scientific researches and publications of scholars: E. Robin, D. Thomas, D. Lough, W. Meider, N. Bazylevych, S. Yeremenko, L. Vashkiv, V. Kuzmenko, V. Galych.

The purpose of this research is to analyse the specific features of the correspondence between Winston Churchill and Franklin Roosevelt and also determine the main genre-style dominants inherent in private and business correspondence between the two outstanding statesmen.

The profound research and analysis of such historians such as Warren F. Kimball and David Reynolds cast the light on the «special relationship» between the USA president, Franklin Roosevelt, and the prime minister of Great Britain, Winston Churchill, in the time of the Second World War, when the two men led the American and British people to victory in their desperate struggle against the "monstrous tyranny» of fascism. The object of the research is a three-volume collection of «Churchill \& Roosevelt: The Complete Correspondence», edited by W. F. Kimball. The three books contain the complete collection of Churchill's 1,161 written messages and telegrams to Roosevelt and F.D.R.'s 788 to him over 1939-1945 years.

The friendship between both political leaders was built on the correspondence initiated by Roosevelt when he sent a letter to Churchill in 1939 after two weeks of the German attack on Poland naming Churchill «the First Sea Lord» who possessed a great interest in and love for the navy. Churchill quickly took advantage of developing closer Anglo-American ties and stronger cooperation as well as cultivating a personal relationship with the president due to their mutual correspondence. "The Naval Person», as Churchill called himself, sent Roosevelt dozens messages dealing with naval matters. The personal line of communication with the president was approved and soon acquired the cordial and informal character. Perhaps, the true nature of their friendship can be found in Roosevelt's attempt to give inspiration for Churchill and for British and American people at the darkest moments of the 
war - January 1941, when Great Britain was desperate for supplies having witnessed the London Blitz. In the letter to Churchill Roosevelt cited a poem «The Building of the Ship» by Henry Longfellow and wrote that «this verse applies to your people as it does for us» [3, p. 131]. Churchill expressed his satisfaction with that gesture and promised the president to have the verse framed «as a mark of our friendly relations which have been built up telegraphically under all the stresses of war» [3, p. 134].

Until the early 1943 Churchill-Roosevelt correspondence had preserved friendly candid informal atmosphere; they sent each other birthday greetings, gifts, «developed of serious of inside jokes, and regularly added a casual informal sentence to drafts of their exchanges, prepared by subordinates» [3, p. 3], as Warren Kimball notes in his Introduction to the first volume of the collection. This personal touch of their correspondence is marked by an easy and affable style of writing and the forms of addressing between the sender and a recipient. Churchill expressed his gratitude for American war aid in the letter dated December 30, 1942, starting with: «Former Naval Person to President Roosevelt Personal and Most Secret, Begins: My Dear Mister President.

1. The letter which Oliver Lyttelton brought and the associated agreement about air and ground force equipment are very welcome. I am deeply grateful» $[4$, p. 93]. The complimentary closing follows the remained semiformal tone although the content of the letter seems to reflect Churchill's pessimistic look at the question of shipping war supplies: «I was also reassured by your resolve to raise the shipbuilding programme to twenty million dead-weight tons, if it should prove feasible. I hope you will be able to give me some good news about the result of this inquiry ....always your sincere friend, Winston S. Churchill. [Mr. PREM. 3/ 470]» [4, p. 96].

The letter of inquiry from the addressee is typical for business communication between both correspondents and is supplemented with other documents such as memoranda, notes and telegrams (even unsent). With the heightened state of tension that appeared in Churchill -Roosevelt alliance «over a host of issues from military strategy to the nature of the economic structure of the postwar world» [7, p. 154], we also notice changes in their personal communication with the shift to more formal language. As a result, the form of addressing becomes more formal and cold. Besides the mentioned formats of business official correspondence a new genre of a letter has become evident which includes reports on the current subject involving feelings of regrets or other author's evaluative elements: criticism or approval. It means the rhetoric of the letters between the two famous world leaders are not devoid of emotive connotations as well as personal comments to underscore emotional states, ranging from frustrations and disappointments to expressions of thankfulness. Besides factual paragraphs relating to pragmatic 
matters there are also passages which contain some words of colloquial language and proverbs by skillfully interweaving in the canvas of the letterreport or a secretive letter-exchange. As for Churchill-Roosevelt correspondence rhetoric, the most distinctive feature is becoming noticeable which makes this correspondence unique, is the use of proverbial expressions, ready-made phrases of folk speech and humour. As W. Mieder claims, «Churchill was perfectly capable of quoting Latin proverbs and sententious remarks but the fact that he did it in this letter adds a bit irony to his statement» [5, p. 21]. On April 5, 1945 Churchill wrote his last message of warm friendship just before the death of the president, where he cited a famous Latin quotation which in English translation is known as «Lovers quarrels are the renewal of love» [5]. This was also the way of expressing Churchill's willingness to continue maintaining his friendship with Roosevelt that «had weathered all storms» throughout the war.

However, Churchill-Roosevelt official business correspondence is more formal than private. Its genres or sub- styles cover the texts of letters, in which the decisive role is played by formal literary vocabulary (the language of memoranda, communiqués), as well as daily business communication (documents with a concise statement of the case without evaluative components of the transmitted content).

Churchill preferred writing memoranda as it was typical of his diplomatic routine practice to exchange documents (notes, memoranda) with high ranking officials. The Cambridge dictionary gives a definition of the word of memorandum or memo as «a short written report prepared specially for a person or group of people that contains information about a particular matter» [1]. As a rule, «it consists of a short official note that is intended to inform or advise one person or the entire staff about matters ranging from internal regulations to announcements regarding specific events» [6, p. 106]. Therefore, memos are usually drafted in a formal and straightforward style. In the Memo on Brevity written on August 9, 1940 the writer shares tips of «keeping things short» and being concise in reports, the need to avoid jargon and «woolly phrases» [2] is also emphasized as the key to express clear thoughts.

As it is observed from the analysed correspondence, Winston Churchill often followed the rule to state the purpose of his letter in the first paragraph and not to veer from the subject. By trying to give a detailed exposition of the factual or legal aspects of a particular issue in a business letter (memo) and avoiding flowery language or long words, he sometimes tends to describe the situation in detail while using a complex sentence. Following one subject of conversation the author could use a complex sentence structure to explain his topic sentence in detail and give evidence, depending on whether it is a letter of Note or any other type of a document enclosed into a letter. Thus, 
Churchill-Roosevelt written messages are well structured entailing textual internal coherence, logical development and the range of language tools used to express the argument precisely, persuasively, with informal touch - these highlighted features constitute the genre-style dominants of ChurchillRoosevelt correspondence which is worth researching.

\section{References:}

1. Cambridge English Dictionary.Cambridge University Press. Retrieved from: https://dictionary.cambridge.org/dictionary/english/memorandum (accessed 20 April 2020).

2. Cowdrey, L. (2013). Churchill's call for brevity. October 17. Retrieved from: https://blog.nationalarchives.gov.uk/churchills-call-for-brevity/ (accessed 5 May 2020).

3. Kimball, F. W (1984). Churchill and Roosevelt. The Complete Correspondence. Vol. 1. Alliance Emerging. October 1933 - November 1942. Princeton, New Jersey: Princeton University Press. $844 \mathrm{p}$.

4. Kimball, F. W. [1984] (2015). Churchill and Roosevelt. The Complete Correspondence. Vol. 2. Alliance Forged. November 1942 -February 1944. Princeton, New Jersey: Princeton University Press. 786 p.

5. Meider, W. (2006). «We Are All in the Same Boat Now»: Proverbial Rhetoric in the Churchill-Roosevelt Correspondence. International Journal of English Studies, vol. 6, no. 1, pp. 1-26.

6. Shiyab, S., \& Halimi, S. (2015). Writing Business Letters Across Languages: A Guide to Writing Clear and Concise Business Letters for Translation Purposes. Cambridge Scholars Publishing. $176 \mathrm{p}$.

7. Toye, R. (ed.) (2017). Winston Churchill: Politics, Strategy and Statecraft. London: Bloomsbury Academic. 248 p. 